\title{
Antioxidant enzyme activities and lipid peroxidation in corn (Zea mays L.) following soil application of superabsorbent polymer at different fertilizer regimes
}

\author{
Sishuai Mao ${ }^{1,2}$, M. Robiul Islam ${ }^{1,2,3}$, Yuegao $\mathrm{Hu}^{2}$, Xin Qian ${ }^{2}$, Fei Chen ${ }^{1}$ and Xuzhang Xue ${ }^{1 \star}$ \\ ${ }^{1}$ National Research Center for Intelligent Agricultural Equipments, Beijing, 100097, P. R. China. \\ ${ }^{2}$ College of Agronomy and Biotechnology, China Agricultural University, Beijing 100193, China. \\ ${ }^{3}$ Department of Agronomy and Agricultural Extension, Rajshahi University, Rajshahi 6205, Bangladesh.
}

Accepted 11 July, 2011

\begin{abstract}
In arid and semiarid regions of northern China, there is an increasing interest in using reduced rate of inorganic fertilizer together with water-saving superabsorbent polymer (SAP) for field crop production. Thus, an efficient management of fertilizer and study of metabolic changes in response to SAP application is important for improved production of corn. 24 undisturbed soil lysimeters $(35 \mathrm{~cm}$ in diameter and $150 \mathrm{~cm}$ in depth) were installed in a field lysimeter facility during 2010, to study yield and physiological mechanisms in corn (Zea mays L.) subjected to application (30 kg ha-1) or without application of SAP at different fertilization levels (standard, medium or $75 \%$ and low or $50 \%$ of conventional fertilization rate). The results show that the corn yield fell by $19.7 \%$ under medium and $37.7 \%$ under low fertilization; the application of SAP increased it significantly by $\mathbf{8 0 . 3 \%}$. Although SAP had marginal effect under standard fertilization, plants treated with SAP under reduced fertilization showed a significant decrease in superoxide dismutase (SOD), catalase (CAT), peroxidase (POD), ascorbate peroxidase (APX) and glutathione reductase (GR) activities in leaves when compared with control plants. Our results suggest that drought stress as well as fertilizer reduction leads to production of oxygen radicals, which results to oxidative stress in the plant and the application of superabsorbent polymer could conserve soil water and nutrients, making same available for plants to reduce oxidative stress and increase biomass accumulation, especially under reduced fertilization level.
\end{abstract}

Key words: Antioxidant enzymes, lysimeter, corn, drought stress, superabsorbent polymer.

\section{INTRODUCTION}

Drought stress limits crop growth and productivity more than any other single environmental factor (Todorov et al., 1998). However, in certain tolerant/adaptable crops, morphological and metabolic changes occur in response to drought, which contribute to adaptation to such unavoidable environmental constraints (Ben-Amor et al., 2007). Efficient management of soil moisture and fertilizer is important for agricultural production in the light of scarce water resources. China has a large region of dry land in the north, which accounts for about $56 \%$ of the

*Corresponding author. E-mail: xuexz@nercita.org.cn. Tel: +86 10 51503591. Fax: +861051503750. nation's total land area but only $24 \%$ of the country's water resources (Xin and Wang, 1999). Northern China is the most important wheat and maize production area in China. The main cropping system in this region is wheat and maize double cropping in a year, producing about $29.6 \%$ of the nation's food, including about half of the wheat and one third of the maize production (NBSC, 1998). The average requirement of water for crop production is about $800 \mathrm{~mm}$ (450 $\mathrm{mm}$ for wheat and $360 \mathrm{~mm}$ for maize), whereas mean annual rainfall is only about $550 \mathrm{~mm}$ (Liu et al., 2001). In recent years, however, increased water deficits associated with overuse of surface water, declining ground water levels, water pollution and soil salini-zation are threatening the sustainability of agricultural production in the region (Hu et al., 2005; Liu et 
al., 2001).

On the other hand, fertilizer utilization in China also challenges the acceptance limit of resource and environment. Excessive application of inorganic fertilizer in China has become a fear factor for long term farmland efficiency and environmental sustainability. In arid and semiarid regions of NCP (double cropping wheat and corn areas), there is a common trend of excessive fertilization (about $600 \mathrm{~kg} \mathrm{ha}^{-1}$ ) for better crop production. Some recent studies (Zhu and Chen, 2002) have shown that most of those applied fertilizer were lost through leaching, resulting to serious environmental hazards, including soil acidification, heavy metal contamination and greenhouse gas emission. Soils in the NCP area are mostly characterized by low water-holding capacity, high evapotranspiration and excessive leaching of rain and irrigation water below the root zone, leading to poor water and fertilizer use efficiency by crops (Wang et al., 2001), while crop productivity is seriously affected by drought stress.

Plant stress invariably leads to oxidative stress in the plant cell due to the higher leakage of electrons towards $\mathrm{O}_{2}$ during photosynthetic and respiratory processes leading to enhancement in reactive oxygen species (ROS) generation (Asada, 1999). The ROS such as $\mathrm{O}_{2}^{-}, \mathrm{H}_{2} \mathrm{O}_{2}$ and $\mathrm{OH}$ radicals have potential to interact with many cellular components, causing significant damage to membrane and other cellular structures, and consequently growth inhibition (Blum, 1996). Some of the ROS are highly toxic and must be detoxified by cellular responses if the plant survives and grows (Drame et al., 2007). The ROS scavenging depends on the detoxification mechanism, which may occur as a result of sequential and simultaneous action of a number of antioxidant enzymes, including superoxide dismutase (SOD), catalase (CAT), peroxidase (POD), ascorbate peroxidase (APX) and glutathione reductase (GR).

Plants under stress exhibit some defense mechanisms to protect themselves from the damaging effect of oxidative stress. Plants with high constitutive and induced antioxidant levels have better resistance to damage (Gigon et al., 2004). The scavenging of ROS is one among the common defense responses against abiotic stresses (Gossett et al., 1994). The degree of damage by ROS depends on the balance between the product of ROS and its removal by these antioxidant scavenging systems (Demiral and Turkan, 2005). When ROS increases, chain reactions start, in which superoxide dismutase (SOD) catalyzes the dismutation of $\mathrm{O}_{2}^{-}$radicals to molecular $\mathrm{O}_{2}$ and $\mathrm{H}_{2} \mathrm{O}_{2}$. CAT and POD catalyze the breakdown of $\mathrm{H}_{2} \mathrm{O}_{2}$. The $\mathrm{H}_{2} \mathrm{O}_{2}$ is then detoxified in the ascorbate-glutathione cycle which involves the oxidation and re-reduction of ascorbate and glutathione through the ascorbate peroxidase (APX) and glutathione reductase (GR) action (Gossett et al., 1994). The increased production of superoxide radicals and $\mathrm{H}_{2} \mathrm{O}_{2}$ was paralleled by malondialdehyde (MDA) accumulation under drought stress (Porcel and Ruiz-Lozano, 2004). MDA is a decomposition product of polyunsaturated fatty acids of biomembranes which is an important indicator of membrane damage (Jiang and Zhang, 2001).

In arid and semiarid regions of northern China, there is an increasing interest in using reduced rate of inorganic fertilizer together with water-saving superabsorbent polymer (SAP) for field crop (such as corn) production (Islam et al., 2011a, b, c). Several studies have confirmed the effectiveness of SAP application for mitigating drought effects on plants (Islam et al., 2011a, b, c; Yazdani et al., 2007). When polymers are incorporated in soil, it is presumed that they retain large quantities of water and nutrients, which are released as required by the plant. Thus, plant growth could be improved with limited water supply (Yazdani et al., 2007). The use of hydrophilic polymer materials as carrier and regulator of nutrient release is helpful in reducing undesired fertilizer losses, while sustaining vigorous plant growth (Mikkelsen, 1994).

Although there is limited understanding of droughttolerance mechanisms, physiological and molecular biological studies have documented several plant responses to drought stress (Luan, 2002). In particular, drought can result in the closure of stomata and increased biosynthesis of the stress hormone, abscisic acid (ABA), as well as the induction of drought and ABA-responsive genes.

Synthetic polyacrylamide with potassium salt base manufactured by Beijing Han Li-sorb Poly-water Hightech Company Limited, which is a cross linked polymer developed to retain water and fertilizer in the agricultural and horticultural sector, was used for the study. Polymers are safe and non-toxic and will finally decompose to carbon dioxide, water, ammonia and potassium ions, without any remainder (Mikkelsen, 1994). The research was aimed also to clarify whether an application of superabsorbent polymer (synthetic poly- acrylamide) to plant might be a strategy for increasing stress tolerance at the phyto-physiological level. The objective was to examine the effect on the activities of different antioxidant enzymes as well as biochemical changes in leaves of corn.

\section{MATERIALS AND METHODS}

\section{Experimental site}

The study was conducted at the National Experimental Station for Precision Agriculture, Xiaotangshan (40॰10' N, $\left.116^{\circ} 27^{\prime} \mathrm{E}\right)$, Beijing, P. R. China during the year, 2010. Climate of the area is continental type and winter temperatures can be as low as $-25^{\circ} \mathrm{C}$ and summer temperature can rise above $40^{\circ} \mathrm{C}$; total rainfall is about $540 \mathrm{~mm}$, being concentrated mainly in June to July (NBSC, 1998). The soil is loamy sand and the background soil characteristics of the experimental plot, determined at the beginning of the experiment are presented in Table 1.

\section{Soil lysimeter sampling and preparation}

To maintain a particular moisture and nutrient status for the treatments, 24 large, undisturbed soil monolith lysimeters $(35 \mathrm{~cm}$ in 
Table 1. Physical and chemical properties of the soil used for this study.

\begin{tabular}{cccccccc}
\hline Depth (cm) & $\begin{array}{c}\text { Clay } \\
(\%)\end{array}$ & $\begin{array}{c}\text { Silt } \\
(\%)\end{array}$ & $\begin{array}{c}\text { Sand } \\
(\%)\end{array}$ & $\begin{array}{c}\text { Bulk density } \\
\left(\mathbf{g ~ c m}^{-3}\right)\end{array}$ & $\begin{array}{c}\text { Total N } \\
\left(\mathbf{g ~ k g} \mathbf{~ k g}^{-1}\right)\end{array}$ & $\begin{array}{c}\text { Available K } \\
\left(\mathbf{m g ~ k g}^{-1}\right)\end{array}$ & $\begin{array}{c}\text { Available P } \\
\left(\mathbf{m g ~ k g}^{-\mathbf{1}}\right)\end{array}$ \\
\hline $0-20$ & 17 & 20 & 63 & 1.39 & 86.2 & 83.5 & 21.5 \\
$20-40$ & 19 & 22 & 59 & 1.41 & 54.1 & 78.3 & 18.3 \\
$40-60$ & 23 & 23 & 54 & 1.45 & 26.8 & 71.2 & 13.7 \\
$60-80$ & 31 & 21 & 48 & 1.51 & 17.5 & 54.7 & 8.1 \\
$80-100$ & 37 & 22 & 41 & 1.54 & 13.3 & 32.1 & 4.3 \\
$100-120$ & 41 & 26 & 33 & 1.58 & 11.4 & 23.6 & 3.4 \\
$120-140$ & 41 & 26 & 33 & 1.58 & 9.8 & 17.4 & 3.2 \\
\hline
\end{tabular}

diameter, $150 \mathrm{~cm}$ in depth and surface area is $962.5 \mathrm{~cm}^{2}$ ) were collected from a corn field in National Experimental Station for Precision Agriculture, Xiaotangshan (40¹0’ N, $116^{\circ} 27^{\prime}$ E), Beijing, P. R. China. The collection of undisturbed soil monolith lysimeters followed the procedure described in Islam et al. (2011d). Each lysimeter casing consisted of a polyvinyl chloride (PVC) cylinder. The lysimeters were transported to a field trench lysimeter facility (5 $\mathrm{m}$ long, $4 \mathrm{~m}$ wide and $2 \mathrm{~m}$ deep) in the National Experimental Station for Precision Agriculture, Beijing, P. R. China.

\section{Treatments and maintenance}

Superabsorbent polymer (granular) was applied at a $20 \mathrm{~cm}$ depth into the lysimeter during seed sowing at the rate of $30 \mathrm{~kg} \mathrm{ha}^{-1}$, whereas the control pots received only inorganic fertilizer but no SAP. The conventional application rate $\left(\mathrm{ha}^{-1}\right)$ of inorganic fertilizers for the experimental area was $300 \mathrm{~kg}$ urea $(\mathrm{N})$, and $100 \mathrm{~kg}$ each of superphosphate $(\mathrm{P})$ and potassium sulfate $(\mathrm{K})$, which was considered as standard fertilization rate. The experiments were conducted under three fertilization levels (conventional standard rate, $75 \%$ of standard rate or medium rate and $50 \%$ of standard rate or low rate). The two SAP application rates (with or without) and three fertilizer regimes were combined to make a total of 6 treatments. The treatments were replicated four times and arranged into a completely randomized design. JingDan 28 (Developed by Beijing Academy of Agriculture and Forestry Science), in northern China commonly grown hybrid grain corn variety (Zea mays L.) was used for the experiment. Seeds were directly sown into the lysimeter on 15th June and harvested on 21st September in 2010. After emergence, seedlings were thinned to one stand per lysimeter.

Nitrogen (urea, $46 \% \mathrm{~N}$ ) was split into base and dressing applications, and phosphate (superphosphate, $5.2 \% \quad \mathrm{P}$ ) and potassium (potassium sulfate, $41.4 \% \mathrm{~K}$ ) fertilizers were applied as base fertilizer. Irrigation was applied immediately after the $\mathrm{N}$ application according to standard practice in the region.

An automatic weather station was installed in the experimental field to record the daily air temperature, rainfall and relative humidity during the experimental period (Figure 1). Air temperature ranged from 5.6 to $40.7^{\circ} \mathrm{C}$ and the mean temperature was $25.0^{\circ} \mathrm{C}$. The total precipitation was $298.7 \mathrm{~mm}$ in 30 rainy days which was $51.3 \mathrm{~mm}$ lower than corn requirements (Liu et al., 2001). Relative air humidity (daily average) ranged from 38.6 to $89.9 \%$ and the mean value was $68.6 \%$. Total irrigation was $60 \mathrm{~mm}$ in three spells which was maintained by observing drought status and plant requirements.

\section{Phenological and physiological measurements and calculation}

Determination of grain yield and biomass accumulation was carried out during the harvest. Relative water content (RWC) of leaves was determined at 3, 6 and 9 weeks after sowing (WAS) by the standard method (Schonfield et al., 1988) according to the following equation:

RWC $(\%)=[($ fresh weight - dry weight $) /($ turgid weight - dry weight $)]$ $\times 100$

At 8 WAS, when plants had attained the maximum vegetative growth stage, SPAD readings were taken using SPAD-502 chlorophyll meter. Readings were taken on about same location of each plant. For biochemical analysis, the samples were collected on 8 WAS. Immediately after collection, the samples were washed and then frozen in liquid nitrogen and stored at $-80^{\circ} \mathrm{C}$.

\section{Lipid peroxidation}

Lipid peroxidation was estimated from the level of malondialdehyde (MDA) production using thiobarbituric acid (TBA) according to Sairam and Srivastava (2001). Fresh leaf $(0.5 \mathrm{~g})$ was homogenized in $5 \mathrm{ml}$ of $0.1 \%$ trichloroacetic acid (TCA) and centrifuged at $10000 \mathrm{~g}$ for $10 \mathrm{~min}$. The mixture (containing $1 \mathrm{ml}$ sample supernatant, $4 \mathrm{ml}$ $20 \% \mathrm{TCA}$ and $0.5 \% \mathrm{TBA}$ ) was heated at $95^{\circ} \mathrm{C}$ for $30 \mathrm{~min}$, quickly cooled and centrifuged at $10000 \mathrm{~g}$ for $10 \mathrm{~min}$. The resulting supernatant was used for spectrophotometric determination of MDA. Absorbance of +TBA was read at 532 and $600 \mathrm{~nm}$ using the corresponding TBA as the blank. The MDA concentrations were calculated according to Du and Bramlage (1992) as follows:

MDA $\left(\mu \mathrm{mol} \mathrm{g}{ }^{-1}\right.$ fresh weight $)=\left[\left(A_{532}-A_{600}\right) / 156\right] \times 103 \times$ dilution factor

\section{Soluble protein content}

Total soluble protein was extracted from $0.5 \mathrm{~g}$ leaf tissue in $5 \mathrm{ml} 0.1$ $\mathrm{M}$ Tris- $\mathrm{HCl}$ ( $\mathrm{pH}$ 7.5) containing $50 \mathrm{mM}$ ascorbic acid, $1 \%$ $\beta$-mercaptoethanol and $1 \mathrm{mM}$ phenylmethylsulfonyl fluoride after centrifugation (15000 $\mathrm{g}$ for $30 \mathrm{~min}$ ) at $4^{\circ} \mathrm{C}$. Protein content was determined by the procedure of Jiang and Huang (2002) using bovine serum albumin as standard.

\section{Assay of antioxidant enzymes}

Frozen leaf tissue $(0.5 \mathrm{~g})$ was homogenized at $4^{\circ} \mathrm{C}$ in $5 \mathrm{ml}$ of $0.05 \mathrm{M}$ sodium phosphate buffer $(\mathrm{pH} 7.0)$ containing $0.1 \mathrm{mM}$ ethylene diamine tetra acetic acid, $1 \mathrm{mM}$ L-isoascorbic acid, $1 \%(\mathrm{w} / \mathrm{v})$ polyvinylpyrrolidone and $0.5 \%(\mathrm{w} / \mathrm{v})$ Triton X-100. Extracts were centrifuged at $15000 \mathrm{~g}$ for $30 \mathrm{~min}$ and the supernatants were used for the assays of enzyme activities. Superoxide dismutase (SOD) 

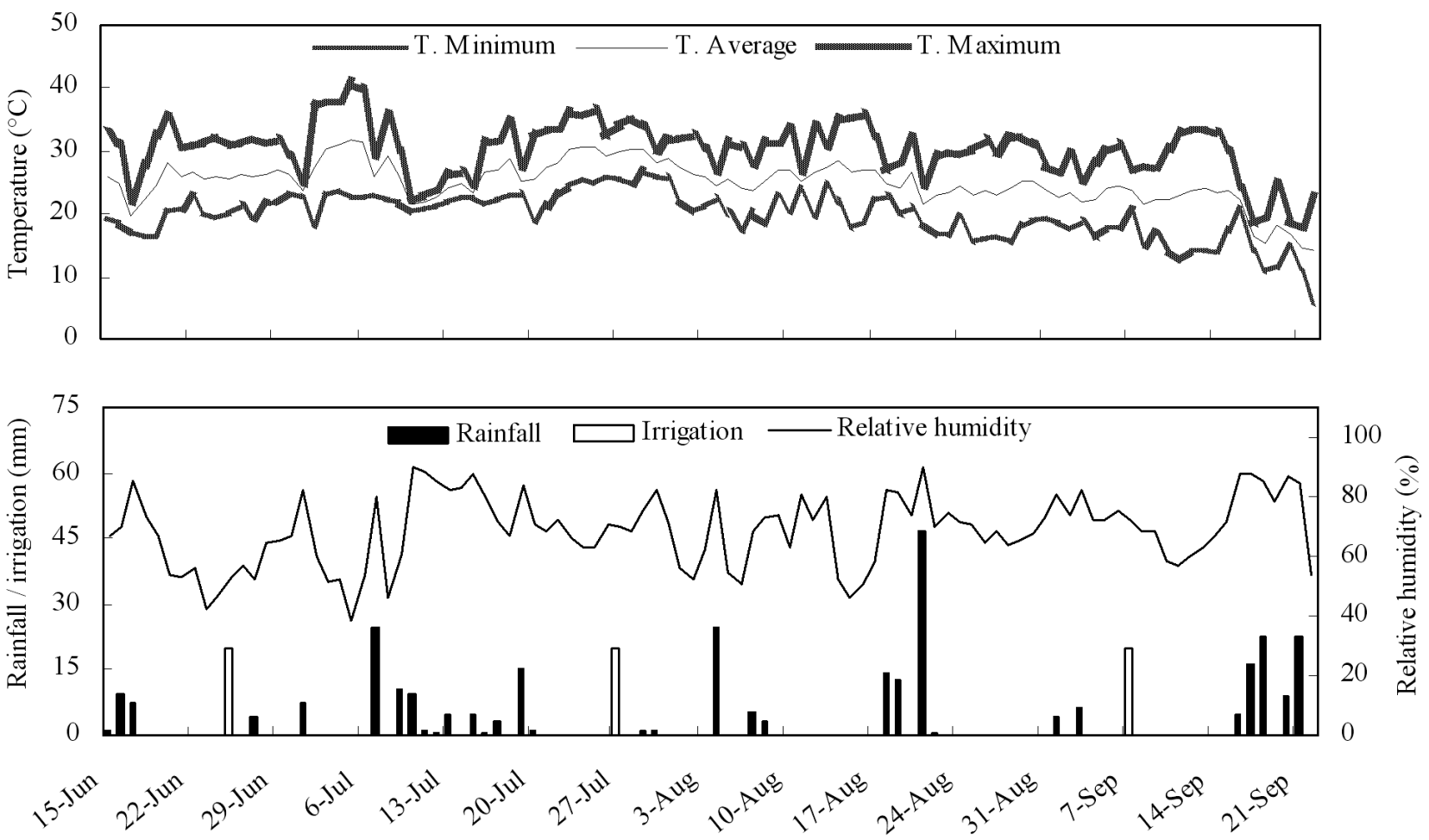

Figure 1. Daily air temperature, rainfall and relative humidity of the experimental field during corn growing season (15th June to 21st September, 2010).

activity was determined according to Sarkar et al. (2001) using the photochemical nitrobluetetrazolium (NBT). One unit of SOD is defined as that which is present in the volume of extract that causes inhibition of the photo reduction of NBT by $50 \%$. Catalase (CAT) activity was estimated by monitoring the disappearance of $\mathrm{H}_{2} \mathrm{O}_{2}$ by recording the decline in absorbance at $240 \mathrm{~nm}$ according to the method of Sairam and Srivastava (2001). The reaction mixture contained $50 \mathrm{mM}$ sodium phosphate buffer ( $\mathrm{pH} 7.0), 15 \mathrm{mM} \mathrm{H}_{2} \mathrm{O}_{2}$ and crude enzyme extract. Peroxidase (POD) activity was determined by recording the oxidation of quaiacol in the presence of $\mathrm{H}_{2} \mathrm{O}_{2}$. The increase in absorbance was recorded at $470 \mathrm{~nm}$ (Hernandez et al., 2000). The reaction mixture contained $100 \mu \mathrm{l}$ crude enzyme, $500 \mu \mathrm{H} \mathrm{H}_{2} \mathrm{O}_{2}, 500 \mu \mathrm{l}$ guaiacol and $1900 \mu \mathrm{l}$ potassium phosphate buffer ( $\mathrm{pH}$ 6.1). Ascorbate peroxidase (APX) activity was measured following the procedure described by Kuk et al. (2003). The reaction mixture contained $50 \mathrm{mM}$ sodium phosphate buffer $(\mathrm{pH}$ 7.0), $0.2 \mathrm{mM}$ EDTA, $0.5 \mathrm{mM}$ ascorbic acid and $0.25 \mathrm{mM} \mathrm{H}_{2} \mathrm{O}_{2}$. APX activity was determined by monitoring the decline in absorbance at $290 \mathrm{~nm}$ for $2 \mathrm{~min}$ as ascorbate was oxidized. Glutathione reductase (GR) activity was assayed by monitoring the glutathione-dependent oxidation of NADPH at $340 \mathrm{~nm}$ by the method of Kuk et al. (2003) in a reaction mixture containing $50 \mathrm{mM}$ sodium phosphate buffer $(\mathrm{pH}$ 7.8), $0.2 \mathrm{mM} \mathrm{NADPH}, 0.5 \mathrm{mM}$ glutathione, $2 \mathrm{mM}$ ethylene diamine tetra acetic acid and enzyme extract.

\section{Soil analysis}

Soils were sampled from the soil sampling point from each lysimeter at 0 to $20 \mathrm{~cm}, 20$ to $40 \mathrm{~cm}, 40$ to $60 \mathrm{~cm}, 60$ to $80 \mathrm{~cm}, 80$ to $100 \mathrm{~cm}$ and 100 to $120 \mathrm{~cm}$ depths before sowing. Air-dried soil samples were ground and passed through $1 \mathrm{~mm}$ sieve before analysis. Total $\mathrm{N}$ was determined by Kjeldhal method (AOAC, 1990). Available $\mathrm{P}$ was determined by the method of Olsen et al. (1954). Available K was measured by analyzing the filtered extract on an atomic absorption spectrophotometer set on emission mode at $776 \mathrm{~nm}$.

\section{Statistical analysis}

An analysis of variance was performed using the STATVIEW software (SAS Institute Inc., Cary, NC, USA) to statistically partition the effects of fertilization and superabsorbent polymer as well as their interactions. Treatment means were compared using the Fisher's protected least significant differences at the $5 \%$ level of probability.

\section{RESULTS}

\section{Grain yield and biomass accumulation}

The maximum grain yield achieved under standard fertilization, was reduced by 19.7 and $37.7 \%$ under medium and low fertilization and the application of SAP increased significantly by $80.3 \%$ (Figure 2). Among the fertilizer regimes, SAP increased grain yield by $64.7 \%$ under standard, $73.7 \%$ under medium and $120.1 \%$ under low fertilization. The stover weight also increased considerably $(P<0.05)$ following the SAP application (Figure 2). Stover weight under adequate irrigation exceeded that under medium and low fertilization by 9.3 and $25.7 \%$, respectively. The total above ground biomass 

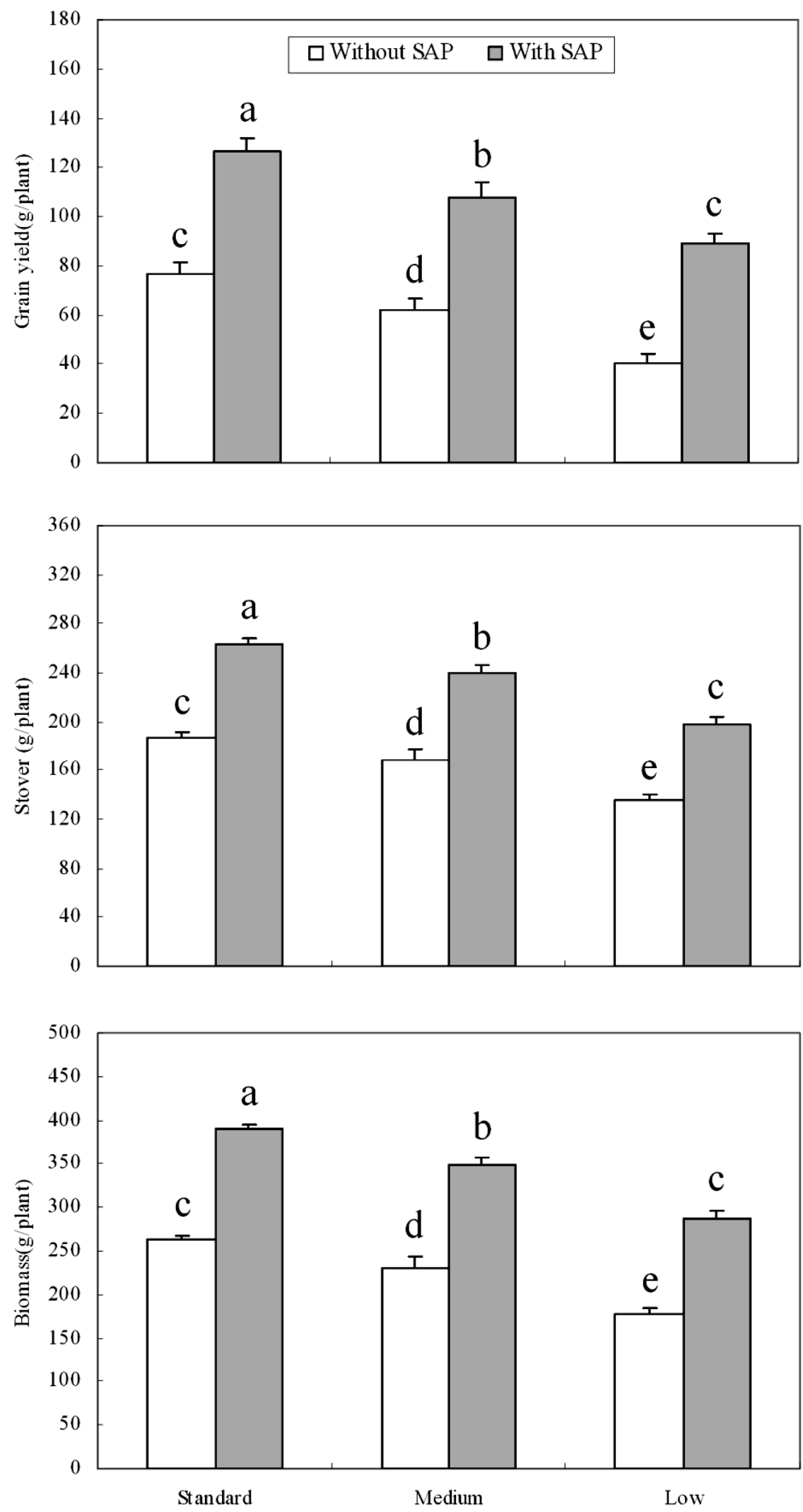

Figure 2. Grain yield and biomass accumulation of corn under different fertilizer and superabsorbent polymer (SAP) treatments. Bars with the same letter do not differ $(P>0.05)$ according to a protected LSD test. 
Table 2. Variation in relative water contents in corn leaves at different growth stages under different superabsorbent polymer (SAP) and fertilizer treatments.

\begin{tabular}{lccc}
\hline Treatment & RWC \% (3 WAS) & RWC \% (6 WAS) & RWC \% (9 WAS) \\
\hline Standard without SAP & $77.08 \pm 3.27$ & $81.11 \pm 1.35$ & $77.33 \pm 2.82$ \\
Medium without SAP & $75.58 \pm 2.06$ & $72.95 \pm 1.58$ & $72.93 \pm 1.67$ \\
Low without SAP & $60.32 \pm 2.32$ & $64.67 \pm 2.34$ & $61.39 \pm 2.14$ \\
Standard with SAP & $86.76 \pm 3.73$ & $83.15 \pm 2.11$ & $83.50 \pm 2.39$ \\
Medium with SAP & $83.05 \pm 2.06$ & $80.68 \pm 2.27$ & $79.33 \pm 1.16$ \\
Low with SAP & $75.97 \pm 2.77$ & $75.10 \pm 1.70$ & $75.40 \pm 2.81$ \\
LSD(0.05) & 8.24 & 5.73 & 6.67 \\
Fertilization (F) & & & \\
Standard & $81.92 \pm 2.94$ & $82.13 \pm 1.22$ & $80.43 \pm 2.07$ \\
Medium & $79.32 \pm 1.95$ & $76.81 \pm 1.94$ & $76.13 \pm 1.53$ \\
Low & $68.15 \pm 3.40$ & $69.89 \pm 2.38$ & $68.39 \pm 3.11$ \\
LSD (0.05) & 8.31 & 5.62 & 6.86 \\
& & & \\
SAP (S) & & & $70.55 \pm 2.35$ \\
Without SAP & $71.00 \pm 2.66$ & $72.91 \pm 2.23$ & $79.42 \pm 1.54$ \\
With SAP & $81.93 \pm 2.04$ & $79.64 \pm 1.47$ & 5.81 \\
LSD (0.05) & 6.95 & 5.55 & 0.17 \\
Interaction (F x S) & 0.33 & 0.11 & \\
\hline
\end{tabular}

LSD, Least significant difference.

accumulation of corn increased significantly by $53.0 \%$ with SAP treatment and the highest value was achieved under standard fertilization (Figure 2). When compared with the standard fertilizer rate, the AGB was reduced by $13.7 \%$ under medium and $29.8 \%$ under low fertilization.

\section{Relative water content}

Table 2 shows the changes in relative water content (RWC) of fully expanded corn leaves (top leaf or flag leaf) under different fertilizer and SAP treatments at different growth stages (3, 6 and 9 WAS or weeks after sowing). The trend in changes of RWC following fertilizer treatments were almost similar across the growth stages, it reduced slightly under medium and significantly under low fertilization when compared with standard fertilizer rate. However, application of SAP increased RWC significantly by $15.4 \%$ at 3 WAS, $9.2 \%$ at 6 WAS and $12.6 \%$ at 9 WAS when compared with those without SAP or control.

\section{SPAD value}

The chlorophyll concentration (SPAD value) in the leaves (Table 3 ) reduced by $15.2 \%$ under medium and $23.3 \%$ under low fertilization when compared with standard rate, whereas the application of SAP significantly increased it by $16.4 \%$. However, the SPAD value changed marginally under standard fertilization with SAP application but increased by 13.0 under medium and $28.6 \%$ under low fertilization.

\section{Soluble protein content}

The application of SAP caused a significant increase $(15.3 \%)$ in total soluble protein contents in the leaves (Table 3), especially under low fertilization. Among the fertilization levels, total soluble protein content was highest under standard fertilization but decreased by 10.6 and $18.4 \%$ under medium and low fertilization, respectively. Total soluble protein changed marginally for SAP application under standard fertilization but increased by 14.4 and $32.2 \%$ under medium and low fertilization.

\section{Lipid peroxidation}

The MDA content in the leaves (Table 3) increased by $13.5 \%$ under medium and $39.2 \%$ under low fertilization when compared with standard rate, whereas the application of SAP significantly prevented lipid peroxidation by reducing the MDA content in the leaves by $13.1 \%$. However, the MDA content under standard fertilization did not changed with SAP application but reduced by 14.7 and $17.2 \%$ under medium and low fertilization, respectively. 
Table 3. Variations in SPAD value, soluble protein content (CP) and malondialdehyde (MDA) in corn leaves under different superabsorbent polymer (SAP) and fertilizer treatments.

\begin{tabular}{lccc}
\hline Treatment & SPAD value & $\mathbf{C P}\left(\mathbf{m g ~ g}^{-1} \mathbf{F W}\right)$ & MDA $\left(\boldsymbol{\mu} \mathbf{m o l ~}^{-1} \mathbf{F W}\right)$ \\
\hline Standard without SAP & $43.00 \pm 1.30$ & $3.87 \pm 0.13$ & $4.43 \pm 0.13$ \\
Medium without SAP & $36.08 \pm 1.69$ & $3.30 \pm 0.13$ & $5.29 \pm 0.21$ \\
Low without SAP & $30.40 \pm 1.48$ & $2.78 \pm 0.12$ & $6.57 \pm 0.20$ \\
Standard with SAP & $45.58 \pm 1.88$ & $4.03 \pm 0.19$ & $4.20 \pm 0.23$ \\
Medium with SAP & $40.78 \pm 1.50$ & $3.77 \pm 0.11$ & $4.51 \pm 0.18$ \\
Low with SAP & $39.10 \pm 1.21$ & $3.67 \pm 0.14$ & $5.44 \pm 0.16$ \\
LSD (0.05) & 4.54 & 0.41 & 0.56 \\
& & & \\
Fertilization (F) & & & $4.32 \pm 0.13$ \\
Standard & $45.29 \pm 1.37$ & $3.95 \pm 0.11$ & $4.90 \pm 0.20$ \\
Medium & $38.43 \pm 1.37$ & $3.53 \pm 0.12$ & $6.01 \pm 0.24$ \\
Low & $34.75 \pm 1.87$ & $3.23 \pm 0.19$ & 0.58 \\
LSD (0.05) & 4.57 & 0.42 & \\
& & & \\
SAP (S) & & $3.32 \pm 0.15$ & $5.43 \pm 0.28$ \\
Without SAP & $36.49 \pm 1.74$ & $3.82 \pm 0.09$ & $4.72 \pm 0.19$ \\
With SAP & $42.48 \pm 1.37$ & 0.36 & 0.70 \\
LSD (0.05) & 4.60 & 0.05 & 0.08 \\
Interaction (F x S) & 0.33 & & \\
\hline
\end{tabular}

LSD, Least significant difference.

\section{Activity of antioxidant enzymes}

SOD activity in the leaves was lowest under adequate irrigation but increased by 13.2 and $29.6 \%$ under medium and low fertilization, respectively (Table 4). Application of SAP had a remarkable $(P<0.001)$ effect, reducing SOD activity by 10.2 and $18.4 \%$ under medium and low fertilization. CAT activity (Table 4 ) reduced significantly $(P<0.0001)$ following SAP application but the activity increased by 20.6 and $54.6 \%$ under medium and low fertilization when compared with standard fertilization. The CAT activity was marginally changed following SAP application under standard fertilization when it was reduced by 20.9 and $26.9 \%$ under medium and low fertilization. A significant increase in POD activities (Table 4) was noted by fertilizer treatments as it increased by $22.8 \%$ under medium and $43.0 \%$ under low fertilization, whereas the activity in plants without SAP exceeded that in plants with SAP by $14.9 \%$. Among the fertilization levels, the application of SAP had no significant effect on POD activity under standard fertilization but reduced it by 17.2 and $18.4 \%$ under medium and low fertilization.

Ascorbate peroxidase (APX) activity (Table 4) significantly increased by 25.9 and $45.7 \%$ under medium and low fertilization and the activity without SAP treatments exceeded $(P<0.01)$ that with SAP by $14.2 \%$. Glutathione reductase (GR) activity (Table 4) also increased under limited fertilization and the value without
SAP exceeded that with SAP by $15.1 \%$.

\section{DISCUSSION}

Superabsorbent polymers have been used as waterretaining materials in agricultural and horticultural fields (Islam et al., 2011a, b,; Yazdani et al., 2007) because when incorporated in soil, they can retain large quantities of water and nutrients. These stored water and nutrients are released slowly as required by the plant to improve growth under limited water supply (Islam et al., 2011a, b). Our data showed that the applied SAP had a remarkable effect on corn growth, especially under limited nutrient supply. Previous research under both field and laboratory conditions also showed similar results (Islam et al., 2011a, b; Yazdani et al., 2007). During our experiment, undisturbed soil monolith lysimeters were used which is highly accurate for maintaining a particular soil fertility status (Islam et al., 2011d). RWC is the appropriate measure of plant water status in terms of the physiological consequence of cellular water deficit, while water potential is an estimate of plant water status and it is useful in dealing with water transport in the soil-plant-atmosphere continuum (Kramer, 1988). In our experiment, we found that the application of SAP substantially increased the RWC at all growth stages, especially under low fertilization (Table 2). 
Table 4. Variation in superoxide dismutase (SOD), catalase (CAT), peroxidase (POD), ascorbate peroxidase (APX) and glutathione reductase (GR) activities in corn leaves under different fertilizer and superabsorbent polymer (SAP) treatments.

\begin{tabular}{|c|c|c|c|c|c|}
\hline Treatment & $\begin{array}{l}\text { SOD (units } \\
\text { mg }^{-1} \text { protein) }\end{array}$ & 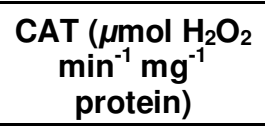 & $\begin{array}{l}\text { POD (Units } \\
\text { mg }^{-1} \text { protein) }\end{array}$ & $\begin{array}{c}\text { APX ( } \mu \text { mol } \\
\text { ascorbate min } \\
\text { mg }^{-1} \text { protein) }\end{array}$ & $\begin{array}{c}\text { GR ( } \mu \text { mol } \\
\text { NADPH min } \\
\text { mg }^{-1} \text { protein) }\end{array}$ \\
\hline Standard without SAP & $77.38 \pm 2.96$ & $75.88 \pm 3.98$ & $291.80 \pm 10.92$ & $334.16 \pm 20.41$ & $36.62 \pm 2.30$ \\
\hline Medium without SAP & $89.57 \pm 2.52$ & $97.33 \pm 5.91$ & $379.30 \pm 11.52$ & $419.91 \pm 13.73$ & $49.59 \pm 3.48$ \\
\hline Low without SAP & $107.20 \pm 4.20$ & $129.03 \pm 3.17$ & $444.64 \pm 15.23$ & $495.18 \pm 15.71$ & $73.63 \pm 5.24$ \\
\hline Standard with SAP & $72.87 \pm 4.08$ & $68.58 \pm 4.18$ & $272.83 \pm 9.17$ & $290.58 \pm 19.32$ & $36.07 \pm 2.35$ \\
\hline Medium with SAP & $80.45 \pm 2.99$ & $76.93 \pm 3.95$ & $314.07 \pm 6.49$ & $366.44 \pm 15.49$ & $44.91 \pm 2.95$ \\
\hline Low with SAP & $87.52 \pm 3.46$ & $94.38 \pm 4.62$ & $362.88 \pm 16.75$ & $415.41 \pm 24.66$ & $54.66 \pm 2.74$ \\
\hline LSD (0.05) & 10.17 & 13.03 & 36.20 & 55.23 & 9.90 \\
\hline \multicolumn{6}{|l|}{ Fertilization (F) } \\
\hline Standard & $75.12 \pm 2.48$ & $72.23 \pm 3.01$ & $282.31 \pm 7.51$ & $312.37 \pm 15.40$ & $36.35 \pm 1.53$ \\
\hline Medium & $85.01 \pm 2.50$ & $87.13 \pm 5.07$ & $346.68 \pm 13.76$ & $393.17 \pm 13.93$ & $47.25 \pm 2.29$ \\
\hline Low & $97.36 \pm 4.49$ & $111.70 \pm 7.04$ & $403.76 \pm 18.67$ & $455.30 \pm 20.26$ & $64.14 \pm 4.51$ \\
\hline LSD (0.05) & 9.69 & 15.60 & 41.40 & 49.26 & 8.97 \\
\hline \multicolumn{6}{|l|}{ SAP (S) } \\
\hline Without & $91.38 \pm 4.08$ & $100.75 \pm 7.00$ & $371.91 \pm 20.01$ & $416.42 \pm 21.70$ & $53.28 \pm 5.05$ \\
\hline With & $80.28 \pm 2.58$ & $79.97 \pm 3.93$ & $316.59 \pm 12.66$ & $357.47 \pm 18.73$ & $45.21 \pm 2.69$ \\
\hline $\operatorname{LSD}(0.05)$ & 10.00 & 16.63 & 49.10 & 59.45 & 11.85 \\
\hline Interaction $(\mathrm{F} \times \mathrm{S})$ & 0.10 & 0.02 & 0.05 & 0.61 & 0.03 \\
\hline
\end{tabular}

LSD, Least significant difference.

Our results suggest that fertilizer application is directly associated with physiological responses in corn plant and its drought status. It leads to production of oxygen radicals as the plants exposed to drought showed a significant increase in SOD, CAT, POD, APX and GR activity (Table 4) in the leaves which resulted in increased lipid peroxidation and oxidative stress in the plant (Table 3). Plant stress may also lead to stomata closure, thereby reducing $\mathrm{CO}_{2}$ availability in the leaves and inhibiting carbon fixation. This exposes the chloroplast to excessive excitation energy, which could in turn increase the generation of free radicals and induce oxidative stress (Islam et al., 2011a, b). The corn plant which is considered moderately drought tolerant (Islam et al., 2011b) might have inadequate ROS scavenging system in addition to other tolerance mechanisms to cope with stress. In our study, the superabsorbent polymer decreased the activity of these enzymes (Table 3 and 4) possibly through the elimination of free radicals. Application of superabsorbent polymer could conserve different amounts of water and nutrients on its own, thereby increasing the soil's capacity for water and nutrient storage and preservation and enhanced growth (Tohidi-Moghadam et al., 2009; Islam et al., 2011d). Thus, under stress condition, the application of superabsorbent polymer would ensure more available water and nutrient for plant and reduce oxidative stress at phyto- physiological levels, resulting to better growth and biomass production. This is the first report on corn at these levels since most of the previous studies with SAP focused mainly on water holding capacity and yield characteristics. Earlier studies on antioxidant enzyme activities and effects of SAP have been reported for different moisture levels (Islam et al., 2011a, b). Differences in responses of corn subjected to SAP application were evident during our observations whereas, the application of SAP increased grain yield by $64.7 \%$ under standard, $73.7 \%$ under medium and $120.1 \%$ under low fertilization. However, under arid and semiarid conditions of northern China or other areas with similar ecologies where poor soil quality leads to low fertilizer use efficiency, application of SAP with reduced fertilization could be a promising fertilizer saving technology and this model could change the fertilization strategy of the region. Further research on SAP application should consider the duration of the effect on the soil and plants and its environmental and economic advantages.

\section{ACKNOWLEDGEMENTS}

This research was supported by grants from Ministry of Agriculture (No. 200903007-1) and Ministry of Science and Technology (No. 2006BAD15B02), P. R. China. 


\section{REFERENCES}

AOAC (1990). (Official Methods of Analysis), 15th ed, Association of Official Analytical Chemists, Washington DC.

Asada K (1999). The water-water cycle in chloroplasts: Scavenging of active oxygens and dissipation of excess photons. Annu. Rev. Plant Physiol. Plant Mol. Biol., 50: 601-639.

Ben-Amor N, Jimenez A, Megdiche W, Lundqvist M, Sevilla F, Abdelly C (2007). Kinetics of the anti-oxidant response to salinity in the halophyte Cakile maritime. J. Integr. Plant Biol., 49: 982-992.

Blum A (1996). Crop responses to drought and the interpretation of adaptation. Plant Growth Regul. 20: 35-148.

Demiral T, Turkan I (2005). Comparative lipid peroxidation, antioxidant defense systems and proline content in roots of two rice cultivars differing in salt tolerance. Environ. Exp. Bot., 53: 247-257.

Drame KN, Clavel D, Repellin A, Passaquet C, Zuily-Fodil Y (2007). Water deficit induces variation in expression of stress-responsive genes in two peanut (Arachis hypogaea L.) cultivars with different tolerance to drought. Plant Physiol. Biochem., 45: 236-243.

Du Z, Bramlage WJ (1992). Modified thiobarbituric acid assay for measuring lipid oxidation in sugar-rich plant tissue extracts. J. Agric. Food. Chem., 40: 1566-1570.

Gigon A, Matos AR, Laffray D, Zuily-Fodil Y, Pham-Thi AT (2004). Effect of drought stress on lipid metabolism in the leaves of Arabidopsis thaliana (ecotype Columbia). Ann. Bot. 94: 345-351.

Gossett DR, Millhollon EP, Lucas MC (1994). Antioxidant response to $\mathrm{NaCl}$ stress in salt-tolerant and salt-sensitive cultivars of cotton. Crop Sci., 34: 706-714.

Hernandez JA, Jimenez A, Mullineaux P, Sevilla F (2000). Tolerance of pea (Pisum sativum L.) to long-term salt stress is associated with induction of antioxidant defenses. Plant Cell. Environ., 23: 853-862.

Hu C, Delgado JA, Zhang X, Ma L (2005). Assessment of groundwater use by wheat (Triticum aestivum L.) in the Luancheng Xian region and potential implications for water conservation in the northwestern North China Plain. J. Soil. Water Conserv., 60: 80-88.

Islam MR, Xue X, Mao S, Ren C, Eneji AE, Hu Y (2011a). Effects of water-saving superabsorbent polymer on antioxidant enzyme activities and lipid peroxidation in oat (Avena sativa L.) under drought stress. J. Sci. Food. Agric., 91: 680-686.

Islam MR, Hu Y, Mao S, Jia P, Eneji AE, Xue X (2011b). Effects of water-saving superabsorbent polymer on antioxidant enzyme activities and lipid peroxidation in corn (Zea mays L.) under drought stress. J. Sci. Food. Agric., 91: 813-819.

Islam MR, Hu Y, Chen F, Qian X, Eneji AE, Xue X (2011c). Application of superabsorbent polymer: A new approach for wheat (Triticum aestivum L.) production in drought-affected areas of northern China. $\mathrm{J}$ Sci. Food. Agric., 9: 304-309.

Islam MR, Mao S, Xue X, Eneji AE, Zhao X, Hu Y (2011d). A lysimeter study of nitrate leaching, optimum fertilization rate and growth responses of corn (Zea mays L.) Following soil amendment with a water-saving superabsorbent polymer. J. Sci. Food. Agric., (Article in press).

Jiang MY, Zhang JH (2001). Effect of abscisic acid on active oxygen species, antioxidative defence system and oxidative damage in leaves of maize seedlings. Plant Cell. Physiol., 42: 1265-1273.
Jiang YW, Huang BR (2002). Protein alterations in tall fescue in response to drought stress and abscisic acid. Crop Sci., 42: 202-207.

Kramer PJ (1988). Measurement of plant water status: Historical perspectives and current concerns. Irrig. Sci., 9: 275-287.

Kuk YI, Shin JS, Burgos NR, Hwang TE, Han O, Cho BH, Jung S, Guh JO (2003). Antioxidative enzymes offer protection from chilling damage in rice plants. Crop Sci., 43: 2109-2117.

Liu CM, Yu JJ, Kendy E (2001). Groundwater exploitation and its impact on the environment in the North China Plain. Water Int. 26: 265-272.

Luan S (2002). Signaling drought in guard cells. Plant Cell. Environ., 25: 229-237.

Mikkelsen RL (1994). Using hydrophilic polymers to control nutrient release. Fertil. Res., 38: 53-59.

National Bureau of Statistics of China (1998). China Statistical Yearbook. China Stat. Press, Beijing.

Olsen SR, Cole CV, Watanabe FS, Dean LA (1954). Estimation of available phosphorus in soils by extraction with sodium bicarbonate. USDA, Washington, DC.

Porcel R, Ruiz-Lozano JM (2004). Arbuscular mycorrhizal influence on leaf water potential, solute accumulation, and oxidative stress in soybean plants subjected to drought stress. J. Exp. Bot., 55: 1743-1750.

Sairam RK, Srivastava GC (2001). Water stress tolerance of wheat (Triticum aestivum L.): Variations in hydrogen peroxide accumulation and antioxidant activity in tolerant and susceptible genotypes. J. Agron. Crop Sci., 186: 63-70.

Sarkar RK, Das S, Ravi I (2001). Changes in certain antioxidative enzymes and growth parameters as a result of complete submergence and subsequent re-aeration of rice cultivars differing in submergence tolerance. J. Agron. Crop Sci., 187: 69-74.

Schonfeld MA, Johnson RC, Carver BF, Mornhinweg DW (1988). Water relations in winter wheat as drought resistance indicator. Crop Sci., 28: 526-531.

Todorov D, Alexieva V, Karanov E (1998). Effect of putrescine, 4-PU-30, and abscisic acid on maize plants grown under normal, drought, and rewatering conditions. Plant Growth Regul. 17: 197-203.

Tohidi-Moghadam HR, Shirani-Rad AH, Nour-Mohammadi G, Habibi D, Mashhadi-Akbar-Boojar M (2009). Effect of super absorbent application on antioxidant enzyme activities in Canola (Brassica napus L.) cultivars under water stress conditions. Am. J. Agic. Biol. Sci., 4: 215-223.

Wang HX, Zhang L, Dawes WR, Liu CM (2001). Improving water use efficiency of irrigated crops in the North China Plain-measurements and modeling. Agric. Water. Manage., 48: 151-167.

Xin NQ, Wang LX, Eds (1999). Dry land-farming in the North China. Jiangsu Science and Technology Press, Jiangsu, P.R. China.

Yazdani F, Allahdadi I, Akbari GA (2007). Impact of superabsorbent polymer on yield and growth analysis of Soybean (Glycine max L.) under drought stress condition. Pak. J. Biol. Sci., 10: 4190-4196.

Zhu ZL, Chen DL (2002). Nitrogen fertilizer use in China-Contribution to food production, impact on the environment and best management strategies. Nutr. Cycl. Agroecosyst., 63: 117-127. 